\title{
Performance of Regulated Markets in Odisha Under New Agricultural Marketing Reforms Regime
}

\author{
Babita Kathayat \\ ICAR-NDRI, Karnal, Haryana-132001, India \\ Corresponding author: babitakathayat1@gmail.com
}

\begin{abstract}
In the aftermath of introduction of major agricultural marketing reforms such as amendment of APMC Act, e-NAM in the state of Odisha, there was hardly any study assessing the performance of regulated markets in Odisha. Therefore present study was undertaken to study the performance of existing regulated markets, scope of e-NAM and various constraints faced by the farmers to market their produce in the state. Both primary as well as secondary data was collected from respective APMCs and AGMARK net portal. Trend analysis was employed to study the pattern of arrival and prices of major commodities. Garret ranking was done to study the constraints faced by farmers. Findings show that state is gearing up to establish the required infrastructure for implementation of e-NAM, arrivals showed mixed trend and lack of remunerative prices and lack of market information emerged as major constraints faced by farmers in the state.

Highlights

(0 Current status of Regulated markets in Odisha.

0 Scope for e-NAM in the state.

(0 Trend in the arrival and prices of major commodities to regulated markets.

0 Constraints analysis of farmers bringing produce to regulated markets.
\end{abstract}

Keywords: Agricultural marketing, APMC Act, e-NAM, AGMARK, farmers, Odisha

As India races towards becoming one of the largest world economies, it must ensure that its primary sector agriculture is also able to achieve its fullfledged growth. According to census 2011, 54.6 per cent of total population is employed in agriculture and allied activities. It contributes 17 per cent to the country's Gross Value Added at current prices during 2015-16 of 2011-12 series. Agriculture and allied sector has been witnessing a fluctuating growth trend; 1.5 per cent in 2012-13 to -0.2 per cent 2014-15 and 1.2 per cent in 2015-16 at 2011-12 base prices while non-agricultural sector is witnessing an average growth rate of around $7 \%$.

Despite having massive food grain production, India faces a sorry state of affairs in terms of undernourished population in India. Nutritious food is not accessible to all in required amounts. According to FAO estimates in 'The State of Food
Security and Nutrition in the World, 2017" report, 190.7 million people are undernourished in India that is one of the largest in the world. Significant level of food losses occur due to inefficient supply chain management. Losses mainly occur at harvest, post-harvest handling, storage, distribution and consumption stages. Regulated market is wholesale market where buying and selling activities are regulated and controlled by the state government through the market committee. Price discovery in regulated market system mainly takes place through open auction method of sale. Regulated markets received special emphasis in sixth five year plan allowing further expansion both in terms of markets and commodities, strengthening open auction system, regulated trading practices of intermediaries and their margins, establishment of rural market where there was no market. During 1960s and 
J) Kathayat

70s major reforms in agricultural marketing were introduced with the adoption of Agricultural Produce Marketing (Regulation) Act popularly known as APMC Act by various states and UTs. These regulations sought to replace previously existing village trader exploitative system and ensure fair prices to farmers as well as food accessibility to all consumers at affordable prices. However this act has not been very successful in meeting its objective of fair price discovery and a transparent system of trading. APMCs over time have grew restrictive and caused fragmentation of markets thereby reducing their efficiency over space and time.

Another Model APMC Act was introduced by Department of Agriculture and Cooperation in 2003 recognizing the lacunas in existing system and following it up with Model APMC Rules shared with states/UTs in 2007 to guide them in implementation process. Assistance in the form of investment subsidy on market infrastructure development programme was provided to states by centre to enable the implementation of model act.

\section{History of Regulated markets in Odisha}

Before independence, food grains and other essential commodities were directly procured from producers by the purchasing agents appointed by state government. Rationing and control in prices were imposed which ensured uniform prices to producers. In 1954, such controls were lifted and producers were no more able to avail the fair deals. This led the state Government to promote market regulation scheme. At first "Hyderabad system" of market regulation was followed in Odisha. Later Orissa Agricultural Produce Markets Act (OAPM) was passed in 1956. This act came into force with effect from 2nd August 1957. Rules were framed in 1958. First regulated market was established in Jatni on $2^{\text {nd }}$ April 1958. At present there are 67 Regulated Market Committees (RMCs) in 30 districts operating under the supervision and control of Odisha State Agricultural Produce Marketing (OSAM) Board. The State has a total of 428 market yards/ sub-yards operating under 67 RMCs covering 55 Revenue SubDivisions of the State. In addition to these markets, there are temporary yards developed to facilitate procurement of paddy in the state. State has also developed 43 Krushak Bazars to enhance farmer's access to market. Union Government has urged Odisha Government to bring amendments in APMC act to facilitate the establishment of e-NAM National Agricultural Market so that existing APMCs can integrate with Pan India Electronic Trading Portal. Market research has not been lacking in Odisha due to unavailability of published data on agricultural marketing. Keeping in view the scarce availability of literature on the studies regarding regulated markets following objectives have been set up.

\section{Objectives}

1. To study physical performance of selected regulated markets in Odisha.

2. To study the scope of e-NAM in agricultural marketing system of the state.

3. To study constraints faced by the farmers in selected regulated markets.

\section{Database \& Methodology}

The present study focuses on performance of regulated markets in Odisha under new marketing reforms regime. To have a representative study of the regulated markets in the state five markets from five different districts are selected. In order to meet the objectives outlined, attempt has been made to capture both primary as well as secondary data. Secondary data is used to capture trend in price and arrival pattern of selected commodities in selected regulated markets. Primary data mainly pertaining to the operational aspect of e-NAM system was collected in February 2018 from Sakhigopal market and OSAM Board, Bhubaneswar. The primary information was collected by interviewing farmers, regulated market officials, OSAM Board officials using a pre-tested structured questionnaire.

\section{Data Collection}

Secondary data related to average monthly prices and monthly arrivals of selected commodity was collected from respective APMCs as well as AGmark portal. Monthly market arrival data of selected commodities in selected markets was collected for last five years(2013-2017) and average monthly prices of selected commodities were selected for atleast 10 years period to analyze the trend. Primary data mainly pertaining to the operational aspect of e-NAM system and its present status 
as well as for constraint analysis was collected in February 2018 from Sakhigopal market and OSAM Board, Bhubaneswar. The primary information was collected by interviewing farmers, traders and market officials using a pre-tested structured questionnaire.

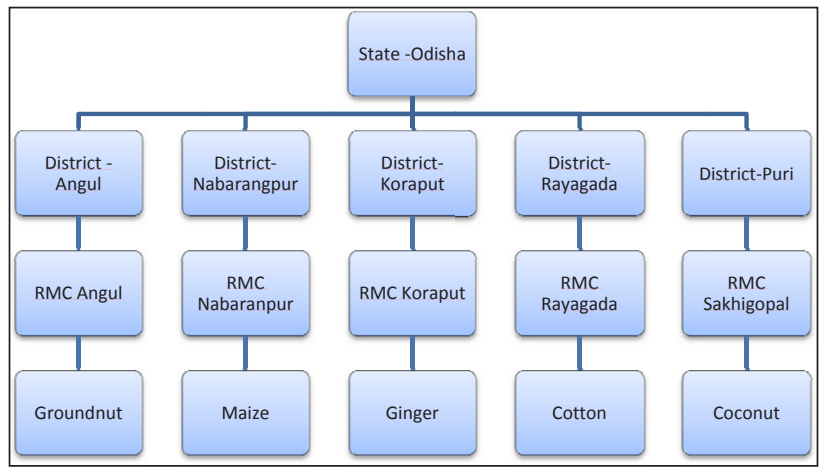

Fig. 1: Sampling design for study of physical performance of selected regulated markets

\section{Analytical Tools and Technique used}

\section{Trend Analysis}

It is technical analysis technique which involves comparison of same item such as monthly market arrivals over a significantly long period of time to spot a pattern. In the present study trend analysis was employed to study the trend of market arrivals and prices of selected commodities in the regulated markets over a period of time. The trend was analyzed by fitting linear regression model of type:

$$
Y=a+b x
$$

$Y=$ Arrivals $/$ prices over a period of time

$a=$ intercept

$b=$ slope

$x=$ time.

\section{Garret Ranking}

Garret ranking is used to find out the most significant factor which influences the respondent. In this method, respondents are asked to assign the rank to all factors as per their preference and outcomes of such ranking have been converted into score value with the help of following formula:

$$
\text { Percent position }=100\left(R_{i j}-0.5\right) / N_{J}
$$

$R_{i j}=$ rank given for $\mathrm{i}^{\text {th variable }}$ by $\mathrm{j}^{\text {th }}$ respondent

$N_{j}=$ number of factors ranked by $j^{\text {th }}$ individual

Garret table is used to convert the percent position into scores. For each factor score assigned by each individual is added and total value and mean value of scores is calculated. Factor having highest mean value is considered to be most significant.

\section{RESULTS AND DISCUSSION}

\section{Current status of regulated markets in Odisha}

At present there are a total of $67 \mathrm{RMCs}$ functional in the state. As per our analysis, maximum number of villages (1794) is served by Jajpur RMC and lowest number of villages served by Jharsuguda RMC (356). The average number of villages served by per regulated market is 424 which is still higher than all India average of 258 villages per regulated market. Analysis of the geographical area served by each regulated market shows that the average area served per regulated market in Odisha is 2324 sq. km. Nayagarh Regulated markets serve maximum area of 3954 sq.km while Jagatsinghpur regulated market serves lowest area (869.5sq.km) among all regulated markets. There is still huge gap between average

\begin{tabular}{|c|c|c|c|c|c|}
\hline S1. No. & Market Name & Commodity & Trend equation & $\mathbf{R}^{2}$ & t-value \\
\hline \multirow[t]{2}{*}{1} & Sakhigopal & Coconut(arrivals) & $Y=-6.413 x+628.8$ & 0.082 & -2.28 \\
\hline & & Coconut( prices) & $y=34.53 x+3260$ & 0.335 & 8.08 \\
\hline \multirow[t]{2}{*}{2} & Rayagada & Cotton(arrivals) & $y=2.269 x+591.21$ & 0.002 & 0.22 \\
\hline & & Cotton(price) & $y=22.33 x+1382.67$ & 0.704 & 17.56 \\
\hline \multirow[t]{2}{*}{3} & Koraput & Ginger(arrivals) & $y=4.413 x+49.108$ & 0.239 & 4.27 \\
\hline & & Ginger(price) & $y=34.89 x+2435.49$ & 0.253 & 6.63 \\
\hline \multirow[t]{2}{*}{4} & Tikabali & Turmeric(arrival) & $y=4.142 x+49.10$ & 0.239 & 4.27 \\
\hline & & Turmeric(price) & $y=22.33 x+1382.67$ & 0.704 & 17.56 \\
\hline \multirow[t]{2}{*}{5} & Nabarangpur & Maize(arrivals) & $y=-103.4 x+12485$ & 0.018 & -1.03 \\
\hline & & Maize (price) & $y=7.828 x+535.4$ & 0.944 & 44.57 \\
\hline
\end{tabular}

Table 1: Trend in arrivals and prices in selected commodities 
C) Kathayat

area served by regulated market in Odisha and national average area of 487.40 sq.km per regulated market.

\section{Trend in monthly market arrivals and prices of selected commodities at respective market}

Linear trend was computed to ascertain the long run movement of market arrivals and prices of selected commodities in the five markets. Trend equation as per Table 2. shows that coefficient of arrival of coconut and maize at Sakhigopal and Nabarangpur mandi were found to be negative which implies that arrivals have been declining over the years. However, decline in coconut was statistically significant at 5 per cent while decline in maize arrivals was statistically insignificant. Coefficient of ginger and turmeric arrivals was found to be positive. The increase in the arrivals has been found statistically significant.

Table 2: Garret ranking of the constraints faced by farmers

\begin{tabular}{ccc}
\hline Constraints & Score & Rank \\
\hline High transportation cost & 67.23 & I \\
Lack of market information & 65.37 & II \\
Non-remunerative price & 64.73 & III \\
Lack of grading facility & 56.87 & IV \\
Exploitation by middlemen & 45.33 & V \\
Lack of storage facility & 43.53 & VI \\
Delayed payment & 41.00 & VII \\
Lack of Access to market credit & 32.63 & VIII \\
Lack of basic amenities such as & 31.4 & IX \\
drinking water, farmer shed. & & \\
\hline
\end{tabular}

Trend component for average monthly prices of selected commodities has been depicted in Table no. Coefficient of average monthly prices is positive for all commodities at selected markets. The increasing trend in the prices was found to be statistically significant for all commodities at selected markets.

\section{Scope of E-NAM in Agricultural Marketing system}

\section{Current status of e-NAM in Odisha}

To study the present scenario of e-NAM in the state, Sakhigopal market was selected where coconut is traded predominantly. Market participants including farmers, traders as well as market officials of OSAM Board were interviewed. Since e-NAM is a recent phenomenon, proper assessment of its achievement could not made in this short duration. As per the interaction, it is found that RMCs in state are still involved in making arrangements for proper infrastructural facilities' such as software, Hardware, grading facilities', etc to upgrade itself into e-NAM. e-NAM in the state is still in nascent stage.

\section{Observation made at Sakhigopal market based on the interaction}

1. Infrastructural facilities required to be put in place for operationalisation of e-NAM are being developed slowly in Sakhigopal market.

2. Grading and analysis lab has been developed for assaying of produce.

3. e-Auction system is not yet started. Sale is done through manual auction system.

4. Registration process for buyers and sellers in e-NAM portal is underway.

5. Farmers were aware that new system of online trading is being implemented but were not aware of its operational aspects and benefit accorded to them. They showed some reluctance towards online payment system as they found it time consuming and preferred cash payment.

6. Traders on the other hand expressed suspicion towards online displayed products. They opined that it was hard to trust the quality of the commodity without physically verifying its quality.

7. Mandi officials have shown optimism with regards to e-NAM. They opined that if implemented effectively, it will bring more transparency and help both farmers and traders in getting better deals.

8. While at the same time, market officials also stressed on several challenges faced in providing the required infrastructure for e-NAM and to convince the farmers and traders to move to online system.

9. e-NAM system still has a long way to go in the state before any conclusion could be drawn. 


\section{Constraint faced by farmers in regulated markets}

Interview of the sample respondents in Sakhigopal market revealed various problems faced by them in the marketing practices followed. The ranking of the constraints along with Garret score is depicted in table 3.1. Study revealed that the major constraint faced by farmers was high transportation cost to bring their produce to market which hindered them to bring the produce to market when production was low. Second most important constraint faced by farmers was lack of market information. Most of the farmers depend on the fellow farmers or neighbourers for market information. Third most important problem ranked by farmers was lack of remunerative price. A majority of them were not satisfied by the prices they were getting. Lack of grading facility was also considered a significant problem ranked fourth. Many farmers complained that due to mixing of good and bad nuts their lot received low prices .Provision of commercial grading has been completely absent in case of coconut. Exploitation by middlemen, lack of storage facility, delayed payment were other constraints which affected farmers satisfaction level with regards to current marketing practices followed in Sakhigopal market. All the stated problems ranked as per the obtained garret score discouraged the farmer-producers to sell their produce through market yard

\section{CONCLUSION \& POLICY IMPLICATION}

Total 67 APMCs are currently operating in the state. On an average 424 villages are served by each APMC compared to national average of 258 villages. Average area served by each APMC in the state is $2324 \mathrm{sq} . \mathrm{km}$ which is still below national average. More market area needs to be brought under regulation. Arrivals of selected commodities are showing mixed trend while prices have been rising over the years. Although dissatisfaction regarding prices received by producers remains a key constraint .e- NAM is still in the nascent stage to conclude anything on its achievement in the state. Required infrastructure for its operation is being developed. State Government must ensure that is implemented in true spirit. One of the severe limitations of this study had been lack of availability of data and past literature regarding regulated markets in the state. More emphasis needs be put in conducting market research time to time in the state so as to assess the efficiency of the existing regulated markets. Accordingly appropriate development measures can be suggested.

\section{REFERENCES}

Aggarwal Nidhi, Sargam Jain and Sudha Narayana. 2017. The long road to transformation of agricultural markets in India: Lessons from Karnataka. Economic \& Political Weekly, 52(41).

Chand Ramesh. 2016. E-Platform for National Agricultural Market. Economic and Political Weekly, 51(28): 15-18.

Chand Ramesh, and Jaspal Singh. 2016. Agricultural Marketing and Farmer Friendly Reforms Across Indian States and UTs. Study Report. National Institution for Transforming India (NITI Aayog) New Delhi.

Chatterjee, Shoumitro and Devesh Kapur. 2016. Understanding Price Variation in Agricultural Commodities in India: MSP, Government Procurement, and Agriculture Markets. Policy Paper. National Council of Applied Economic Research (NCAER), New Delhi.

GOI (Government of India) 2016. Agriculture: More From Less. In: Economic Survey 2015-16, Ministry of finance, Government of India, Oxford University Press, New Delhi, pp. 68-83.

Gosh, Nilabja. 2013. India's Agricultural Marketing: Market Reforms and Emergence of New Channels, Springer India, New Delhi.

Kerur,N.M. 2007. Policy reforms and performance of regulated markets in Karnataka. Thesis PhD. University of Agricultural Sciences, Dharwad, Karnataka.

Naik, R.B., Navadkar, D.S. and Amale, A.J. 2016. Econometric Analysis of Arrivals and Prices of black Gram in western Maharashtra. Agricultural Situation in India, 72(11): 32-37.

Raka Saxena et al. 2016. How equipped are the regulated agricultural markets? Evidences based on selected markets in Uttarakhand. Economic Affairs, 61(2): 203-213

Seepana, Suresh. 2014. Market integration in major cotton markets in India. Thesis Msc (Ag.) Punjab Agricultural University, Ludhiana.

Singh Dhiraj, K., Pynbianglang, K. and Pandey, N.K. 2017. Market Arrival and Price Behaviour of Potato in Agra District of Uttar Pradesh. Economic Affairs, 62(2): 341-345.

Singh, Sukhpal. 2016. Final report on Innovative Agricultural Input Marketing Models in India: Performance and Potential. Ministry of Agriculture, Co-operation, and Farmer Welfare (MoACFW), Government of India, New Delhi.

Yadav, Shalendra. 2017. Odisha-linking farmers to electronic markets current scenario and a way forward. Report submitted to Odisha State Agricultural Marketing Board, Bhubaneswar. 
